\title{
PENGARUH INTENSITAS SINAR LED TERHADAP PERUBAHAN WARNA RESIN KOMPOSIT FLOWABLE
}

\author{
Irsan Ibrahim",***, Prima Luthfia* ${ }^{* *}$ Muhammad Reggy Akbar ${ }^{* * *}$, Chici Karina"** \\ "Departemen IMTKG, Fakultas Kedokteran Gigi, Universitas Prof.Dr.Moestopo (Beragama), Jakarta \\ ${ }^{* *}$ Dokter gigi, RSIA Resti Mulya Penggilingan \\ ${ }^{* * *}$ Mahasiswi Program Profesi Kedokteran Gigi Fakultas Kedokteran Gigi Universitas. Prof. Dr. Moestopo (Beragama) \\ Korespondensi: irsan_henshin@yahoo.com
}

\begin{abstract}
ABSTRAK
Latar belakang: resin komposit memiliki beberapa sifat yaitu menyerupai warna gigi dan dapat diaplikasikan langsung ke dalam kavitas gigi sehingga memiliki keuntungan dalam segi estetika dan waktu. Resin kompositflowable adalah salah satu jenis resin komposit yang memiliki tingkat viskositas yang rendah dan banyak digunakan pada kavitas servikal, pasien anak-anak dan restorasi pada bagian yang tidak mendapatkan tekanan yang tinggi. Salah satu penyebab perubahan warna pada resin komposit adalah polimerisasi yang tidak sempurna yang diakibatkan oleh kurangnya waktu penyinaran ataupun rendahnya intensitas sinar LED. Tujuan: menjelaskan pengaruh perbedaan intensitas sinar LED terhadap perubahan warna pada resin komposit flowable. Metode: penyinaran dilakukan pada intesitas sinar LED $2400 \mathrm{~mW} / \mathrm{cm} 2$ selama 2 detik dan intesitas sinar LED $600 \mathrm{~mW} / \mathrm{cm}^{2}$ selama 20 detik untuk melihat perbedaan warna pada resin komposit flowable. Pengukuran warna resin komposit dilakukan menggunakan spectrophotometer Vita EasyShade untuk melihat nilai light, chrome, dan hue pada resin komposit. Analisis data menggunakan uji parametrik T-test Independent. Hasil: terdapat perbedaan yang signifikan pada nilai light, chrome, dan hue pada pada resin komposit flowable yang disinar dengan intensitas sinar LED $2400 \mathrm{~mW} / \mathrm{cm}^{2}$ dan dengan intensitas sinar LED $600 \mathrm{~mW} / \mathrm{cm} 2$. Kesimpulan: terjadi perubahan yang signifikan pada warna light, chrome, dan hue pada pada resin komposit flowable yang disinar dengan intensitas sinar LED $2400 \mathrm{~mW} / \mathrm{cm}^{2}$ selama 2 detik.
\end{abstract}

Kata kunci: intensitas, LED, Warna, Resin Komposit, Flowable

\section{ABSTRACT}

Background: composite resin has several properties, namely tooth color resembling and can be applied directly to the tooth's cavity so that it has advantages in terms of aesthetics and time. Flowable composite resin is a type of composite resin with a low viscosity level. It is widely used in cervical cavities, pediatric patients and restorations in parts that do not get high pressure. One of the causes of discoloration in composite resins is incomplete polymerization caused by lack of exposure time or low LED light intensity. Purpose: to explain the effect of different LED light intensities on color changes in flowable composite resin. Methods: irradiation was carried out at an LED light intensity of $2400 \mathrm{~mW} / \mathrm{cm}^{2}$ for 2 seconds and an LED light intensity of $600 \mathrm{~mW} / \mathrm{cm}^{2}$ for 20 seconds to see the difference in color on the flowable composite resin. Composite resin color measurements were carried out using a Vita EasyShade spectrophotometer to see the composite resin's light, chrome, and hue values. Data analysis used the parametric t-test Independent. Results: there were significant differences in the values of light, chrome, and hue in the flowable composite resin which was illuminated with an LED light intensity of $2400 \mathrm{~mW} / \mathrm{cm}^{2}$ and an LED beam intensity of 600 $\mathrm{mW} / \mathrm{cm}^{2}$. Conclusion: there were significant changes in light, chrome, and hue colors on the flowable composite resin illuminated an LED light intensity of $2400 \mathrm{~mW} / \mathrm{cm}^{2}$ for 2 seconds.

Keywords: intensity, LED, Color, Composite Resin, Flowable

\section{PENDAHULUAN}

$\mathrm{R}$ esin komposit adalah salah satu bahan restorasi dalam bidang kedokteran gigi yang umum digunakan saat ini. Resin komposit memiliki keunggulan dalam bidang estetik karena sewarna dengan gigi dan mampu diaplikasikan secara langsung ke dalam kavitas dengan baik sehingga menguntungkan dalam segi waktu dan biaya. Resin komposit dapat 
digunakan pada hampir semua permukaan gigi dan semua jenis restorasi. Resin komposit semula banyak digunakan sebagai restorasi anterior karena memiliki estetik yang baik, bahan dan teknik komposit terus berkembang sehingga resin komposit dapat diaplikasikan untuk gigi posterior. ${ }^{1}$

Komponen utama resin komposit terdiri dari tiga yaitu matriks resin organik, bahan pengisi anorganik (filler), dan bahan pengikat (coupling agent) yang mengikat antara bahan pengisi anorganik dan matriks resin, juga aktivator-aktivator diperlukan untuk polimerisasi resin. Penambahan partikel bahan pengisi ke dalam matriks resin secara signifikan meningkatkan sifatnya, seperti berkurangnya pengkerutan karena jumlah resin sedikit, berkurangnya penyerapan air ekspansi koefisien panas, dan meningkatkan sifat mekanis misalnya kekuatan, kekakuan, kekerasan dan ketahanan abrasi. Faktor-faktor lain yang menentukan sifat dan aplikasi klinis komposit adalah jumlah bahan pengisi yang ditambahkan, ukuran partikel dan distribusinya, radiopak, dan kekerasan. Sejumlah kecil bahan tambahan lain seperti bahan penghambat polimerisasi, opasitas, penyerap sinar ultra violet (UV) pigmen warna yang dapat meningkatkan stabilitas warna (penyerap sinar ultra violet) dan mencegah polimerisasi dini. ${ }^{2}$

Penggunaan resin komposit flowable direkomendasikan oleh pabrik untuk penggunaan gigi anterior dan gigi poterior. Resin komposit flowable mempunyai viskositas rendah dan flow komposit yang tinggi, oleh karena itu dianjurkan untuk berbagai aplikasi seperti resin restorasi preventif, cavity liner, perbaikan restorasi dan restorasi pada servikal. ${ }^{3}$ Penggunaan resin komposit flowable paling umum sebagai tambahan pada dinding gingiva restorasi resin komposit klas II gigi posterior Resin komposit flowable mempunyai sifat fisik yang lebih rendah dibandingkan dengan restorasi komposit. Sifat flow yang tinggi memudahkan pengaplikasian resin komposit ini untuk merestorasi kavitas fissure, lesi servikal restorasi pada anak anak dan restorasi yang kecil, restorasi penahan tekanan rendah, restorasi klas $\mathrm{V}$ tanpa lesi karies yang dikarenakan oleh abrasi sikat gigi, erosi asam, atau tekanan oklusal seperti bruxisme, yang memicu pengasahan gigi abrasi. Resin Komposit flowable ini mengerut lebih banyak saat berpolimerisasi daripada komposit hibrid karena resin komposit flowable ini lebih encer. ${ }^{3}$

Resin komposit flowable di kemas dalam bentuk syringe untuk mempermudah pengaplikasiannya. Resin komposit ini digunakan untuk aplikasi langsung pada kavitas atau permukaan gigi. Lamanya penetrasi resin komposit harus seminimal mungkin dibandingkan dengan pengisian komposit. ${ }^{3}$ Faktor-faktor yang berpengaruh dalam keberhasilan restorasi resin komposit adalah pemilihan bahan yang tepat, sistem bonding dan derajat polimerasi. ${ }^{4}$ Polimerasi adalah suatu proses pembentukan polimer yang merupakan gabungan dari berberapa monomer. ${ }^{5}$ Masalah yang sering dihadapi dalam restorasi resin komposit adalah tidak sempurnanya polimerasi. yang dapat disebabkan karena adanya sisa monomer yang didefinisikan sebagai derajat polimerasi. Derajat polimerasi resin komposit sinar dipengaruhi oleh faktor instrinsik dan ekstrinsik. ${ }^{6}$

Faktor instrinsik adalah komposisi material resin komposit, bahan matriks (organik), tipe dan kandungan bahan pengisi (anorganik), viskositas, dan ketebalan lapisan resin komposit. Faktor ekstrinsik adalah LCU (light curing units), intensitas dan waktu pemaparan sinar metode aktivasi sinar tampak serta suhu. light curing units adalah salah satu alat yang paling penting pada restorasi kedoktertan gigi yang berhubungan dengan derajat polimerasi. ${ }^{4}$ light curing units yang paling sering digunakan dalam proses polimerasi adalah LED (light emiting diodem) lebih banyak memliki keuntungan dibandingkan light curing units lainnya, QTH (quartz-tungsten-halogen) memiliki keunggulan biaya lebih rendah tetapi kerugiannya yaitu memiliki suhu yang lebih tinggi, PAC (plasma arc curring) memancarkan intensitas yang lebih tinggi dan di rancang untuk menghemat waktu iradiasi dan Argon laser lamp. ${ }^{7}$

Light Emiting Diode (LED) adalah sinar biru dengan daya yang rendah.pada generasi pertamanya LED menggunakan silicon karbida dengan daya $7 \mu \mathrm{W}$ sedangkan generasi kedua menggunakan gallium nitride dengan daya yang lebih besar yaitu $3 \mathrm{~mW}$. Kelebihan dari LED adalah tidak memerlukan filter karena memancarkan cahaya pada panjang gelombang tertentu pada photo absortion comphorquinone yaitu 400-500 nm, dan sinar yang dipancarkan berguna dalam polimerasi, karena memliki kemampuan yang konstan tanpa penurunan intensitas pemakaian dan tidak terlalu sering memerlukan penggantian diode, jadi panas tidak dihasilkan selama pemakaian LED. ${ }^{4}$ LED (Light Emiting Diode) dikembangkan pada saat ini sudah dilengkapi dengan berberapa teknik penyinaran yaitu Fast curring (metode konvensional) dan soft start (metode lambat) lalu macam macam teknik penyinaran yang direkomendasikan saat ini adalah untuk mengatasi masalah pengerutan polimerasi. ${ }^{4}$

Ilday dkk (2013) menyatakan bahwa pada hasil efek dari light curing unit, curing time dan bahan veneering pada semen resin microhardness mengungkapkan perbedaan yang signifikan dalam kekerasan mikro yang dihasilkan dari unit curing yang berbeda, bahan veneer dan waktu polimerasi. LED curing unit menghasilkan nilai kekerasan mikro yang lebih tinggi dibandingkan dengan sumber cahaya halogen dan PAC. Perpanjangan waktu polimerasi meningkatkan nilai kekerasan mikro permukaan rata-rata dari spesimen resin komposit. ${ }^{7}$

Sri Lestari (2012) menyatakan Efek lama penyinaran terhadap kebocoran tepi tumpatan resin 
komposit floawable dari kecil ke besar adalah dengan lama penyinaran 40 detik 60 detikdan 20 detik, lama penyinaran yang paling efisien dalam menghasilkan kebocoran tepi minimal adalah 40 detik. Nugrahenny (2016) menyatakan bahwa Pengaruh intensitas sinar dengan menggunakan teknik penyinaran yang berbeda menunjukkan bahwa terdapat perbedaan antara kekerasan mikro pada resin komposit., Tujuan penelitian ini adalah mengetahui terdapat pengaruh intensitas sinar LED $2400 \mathrm{~mW} / \mathrm{cm} 2$ selama 2 detik dengan mode Turbo dan intensitas sinar LED 600 $\mathrm{mW} / \mathrm{cm} 2$ selama 20 detik dengan mode Low terhadap perubahan warna resin komposit flowable.

\section{METODE PENELITIAN}

Jenis penelitian yang digunakan dalam penelitian ini adalah eksperimental murni dengan desain penelitian Pretest and Postest Control Grup Design. Spesimen yang digunakan berdiameter $6 \mathrm{~mm}$ dan tebal $2 \mathrm{~mm}$, yang terbuat dari bahan komposit flowable (AnyCom ${ }^{\mathrm{TM}}$ Flow A2, Mediclus Co. Ltd, Korea). Spesimen untuk 2 kelompok penyinaran yaitu kelompok kontrol LED $600 \mathrm{~mW} / \mathrm{cm}^{2}$ dan kelompok LED $2400 \mathrm{~mW} / \mathrm{cm}^{2}$, sehingga masing-masing kelompok berjumlah 16 buah, jadi total spesimen adalah 32 buah.

Pembuatan lempeng akrilik dan pengukuran perubahan warna dilakukan di Laboratorium Dental Material FKG UPDM (B) dengan prosedur sebagai berikut. Pembuatan mold berukuran tebal $2 \mathrm{~mm}$ dan diameter $6 \mathrm{~mm}$ dari stainless steel. Kemudian mold dibuka, letakkan cellophan strips agar spesimen mudah dilepaskan dan memiliki permukaan yang halus. Satukan mold kembali, kemudian ambil resin komposit dengan menggunakan instrumen plastis, masukkan pada mold berukuran diameter $6 \mathrm{~mm}$ dan tebal $2 \mathrm{~mm}$. Letakkan Cellophan strips lain di atas mold yang telah terisi kemudian resin komposit dipadatkan dan diberi tekanan konstan. Resin komposit flowable kemudian disinari dengan menggunakan LED selama 20 detik untuk kelompok kontrol dan dengan LED $2400 \mathrm{~mW} / \mathrm{cm}^{2}$ (LEDEX WL-090, Dentmate, Taiwan) selama 2 detik untuk kelompok perlakuan sesuai petunjuk pabrik. Setelah sampel mengeras, molddibuka dan sampel diambil. Tandai bagian bawah sampel yang tidak disinari dengan menggunakan spidol. Pengukuran pewarnaan dilakukan dengan alat uji pewarnaan Spectrophotometer Uv-Visible (Vita Easyshade V, VITA Zahnfabrik, USA) . Sehingga didapatkan nilai hue, value, dan chrome pada masingmasing kelompok.

Hasil data yang telah didapat akan dianalisis dengan statistik adalah data hasil dari pengaruh intensitas sinar LED $2400 \mathrm{~mW} / \mathrm{cm} 2$ selama 2 detik dan intensitas sinar LED $600 \mathrm{~mW} / \mathrm{cm} 2$ selama 20 detik terhadap penilaian perbedaan warna pada resin komposit flowable. Data tersebut terlebih dahulu dilakukan uji normalitas untuk mengetahui bahwa sebaran data normal. Jika uji normalitas terpenuhi maka dapat digunakan uji parametrik t-tidak berpasangan terhadap kelompok perilaku.

\section{HASIL PENELITIAN}

Berdasarkan penelitian yang telah dilakukan, diperoleh data perubahan warna terhadap nilai light, chrome, dan hue pada resin komposit flowable dijelaskan pada tabel 1 dan dirangkum dalam rerata tabel 2.

Tabel 1. Warna dari resin komposit flowable disinari dengan intensitas sinar LED $2400 \mathrm{~mW} / \mathrm{cm}^{2} \mathrm{dan}$ intensitas sinar LED $600 \mathrm{~mW} / \mathrm{cm}^{2}$

\begin{tabular}{|c|c|c|c|c|c|c|}
\hline \multirow{2}{*}{$\begin{array}{c}\text { Sampel } \\
\text { ke-n }\end{array}$} & \multicolumn{3}{|c|}{ Intensitas $2400 \mathrm{~mW} / \mathrm{cm}^{2}$} & \multicolumn{3}{|c|}{ Intensitas $600 \mathrm{~mW} / \mathrm{cm}^{2}$} \\
\hline & Light & Chrome & Hие & Light & Chrome & Hие \\
\hline $\mathrm{n} 1$ & 3.5 & 3.4 & 3.7 & 0.9 & 0.6 & -0.5 \\
\hline $\mathrm{n} 2$ & 4.0 & 3.3 & 3.0 & 0.3 & 1.0 & -0.3 \\
\hline n3 & 3.5 & 4.6 & 3.7 & 0.3 & 1.1 & -0.7 \\
\hline $\mathrm{n} 4$ & 3.3 & 3.3 & 3.9 & -0.3 & 0.6 & -0.7 \\
\hline n5 & 2.9 & 2.8 & 3.0 & 0.6 & -0.9 & -0.3 \\
\hline n6 & 2.7 & 3.0 & 4.4 & -0.6 & 0.7 & -0.4 \\
\hline n7 & 3.7 & 2.7 & 3.7 & 1.4 & -0.5 & -0.7 \\
\hline $\mathrm{n} 8$ & 4.3 & 2.0 & 3.3 & 0.6 & 1.2 & -0.8 \\
\hline n9 & 2.9 & 2.9 & 3.2 & 0.6 & 0.9 & -0.7 \\
\hline $\mathrm{n} 10$ & 3.4 & 4.1 & 3.3 & 0.8 & 1.1 & -1.0 \\
\hline $\mathrm{n} 11$ & 2.6 & 3.8 & 3.4 & 1.4 & -0.3 & -0.7 \\
\hline $\mathrm{n} 12$ & 2.7 & 2.7 & 3.6 & 1.6 & -0.3 & -0.9 \\
\hline n13 & 3.4 & 2.6 & 3.8 & 0.4 & 0.9 & -0.1 \\
\hline $\mathrm{n} 14$ & 3.3 & 3.6 & 3.8 & 1.7 & 0.3 & -0.6 \\
\hline $\mathrm{n} 15$ & 2.5 & 3.9 & 4.3 & 0.7 & -0.6 & -0.8 \\
\hline $\mathrm{n} 16$ & 2.9 & 3.1 & 3.4 & 0.9 & -0.3 & -0.3 \\
\hline
\end{tabular}


Tabel 2. Rerata Warna dari Resin komposit flowable disinar dengan intensitas sinar LED $2400 \mathrm{~mW} / \mathrm{cm}^{2} \mathrm{dan}$ intensitas sinar LED $600 \mathrm{~mW} / \mathrm{cm}^{2}$

\begin{tabular}{lcccc}
\hline \multirow{2}{*}{ No } & Rerata & Light & Chrome & Hue \\
\cline { 3 - 5 } & & 3.20 & 3.24 & 3.59 \\
\hline 1 & Intensitas $2400 \mathrm{~mW} / \mathrm{cm}^{2}$ & 0.70 & 0.34 & -0.59 \\
\hline
\end{tabular}

Dari Tabel 2 diketahui pada kelompok perlakuan dengan intensitas sinar LED $2400 \mathrm{~mW} /$ $\mathrm{cm}^{2}$ dan intensitas sinar LED $600 \mathrm{~mW} / \mathrm{cm}^{2}$ terdapat perbedaan rerata light, chrome, dan hue. Perbedaan warna di antara masing-masing kelompok perlakuan dapat dilihat pada gambar Gambar 1.

Berikut hasil penelitian pengaruh perbedaan intensitas sinar LED $2400 \mathrm{~mW} / \mathrm{cm}^{2}$ dan intensitas sinar LED $600 \mathrm{~mW} / \mathrm{cm}^{2}$ resin komposit flowable.

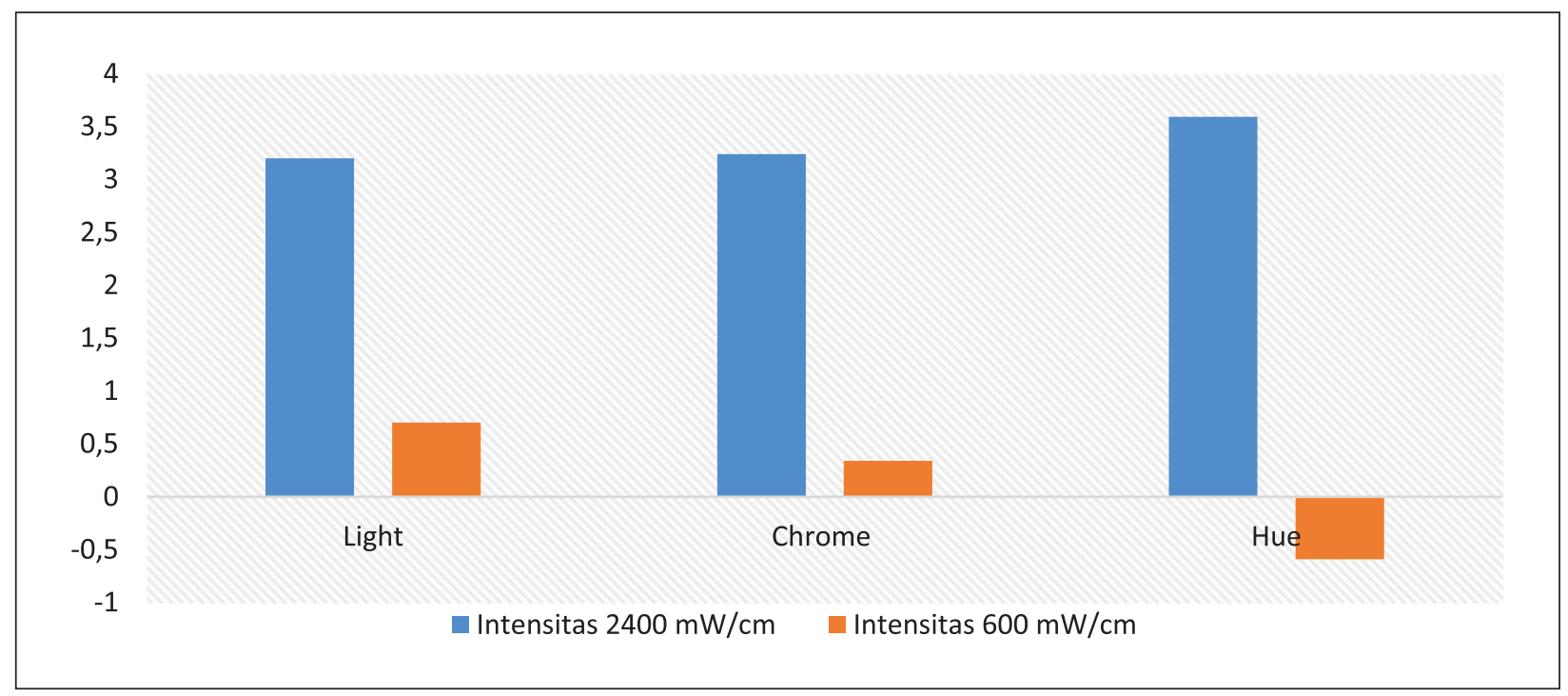

Gambar 1. Grafik rerata warna dari resin komposit flowable disinar dengan intensitas sinar LED $2400 \mathrm{~mW} / \mathrm{cm}^{2} \mathrm{dan}$ intensitas sinar LED $600 \mathrm{~mW} / \mathrm{cm}^{2}$

Syarat uji parametrik adalah distribusi data harus normal. Normalitas distribusi data dalam penelitian ini adalah uji Shapiro-Wilk karena jumlah sampel dalam penelitian ini kurang dari 50. Uji normalitas data dijelaskan pada tabel 3

Tabel 3. Uji Normalitas Data

\begin{tabular}{ccc}
\hline Warna & Intensitas & $\begin{array}{c}\text { Shapiro-Wilk } \\
\text { Sig. }\end{array}$ \\
\hline \multirow{2}{*}{ Light } & Intensitas $2400 \mathrm{~mW} / \mathrm{cm}^{2}$ &, 283 \\
& Intensitas $600 \mathrm{~mW} / \mathrm{cm}^{2}$ &, 566 \\
\hline \multirow{2}{*}{ Chrome } & Intensitas $2400 \mathrm{~mW} / \mathrm{cm}^{2}$ &, 983 \\
& Intensitas $600 \mathrm{~mW} / \mathrm{cm}^{2}$ &, 052 \\
\hline \multirow{2}{*}{ Hue } & Intensitas $2400 \mathrm{~mW} / \mathrm{cm}^{2}$ &, 456 \\
& Intensitas $600 \mathrm{~mW} / \mathrm{cm}^{2}$ &, 354 \\
\hline
\end{tabular}


Dari hasil uji normalitas data terlihat bahwa seluruh data berdistribusi data normal karena ( $\mathrm{p}>$ 0,05), maka akan digunakan uji t-Test independent untuk menguji hipotesa apakah terdapat perbedaan pengaruh intensitas sinar LED $2400 \mathrm{~mW} / \mathrm{cm}^{2}$ selama 2 detik dan intensitas sinar LED $600 \mathrm{~mW} / \mathrm{cm}^{2}$ selama 20 detik terhadap warna light, chrome, dan hue pada resin komposit flowable.

Tabel 4. Hasil Uji T-Test Independent

\begin{tabular}{cc}
\hline & Sig. (2-tailed) \\
\hline Light Intensitas $2400 \mathrm{~mW} / \mathrm{cm}^{2}-$ Light Intensitas $600 \mathrm{~mW} / \mathrm{cm}^{2}$ &, 000 \\
Chrome Intensitas $2400 \mathrm{~mW} / \mathrm{cm}^{2}-$ Chrome Intensitas $600 \mathrm{~mW} / \mathrm{cm}^{2}$ &, 000 \\
Hue Intensitas $2400 \mathrm{~mW} / \mathrm{cm}^{2}-$ Hue Intensitas $600 \mathrm{~mW} / \mathrm{cm}^{2}$ &, 000 \\
\hline
\end{tabular}

Hasil uji t- $T$ independent menunjukan sig. $\mathrm{p}<0,05$ maka kesimpulannya adalah terjadi perubahan yang signifikan pada warna light, chrome, dan hue pada pada resin komposit flowable yang disinar dengan intensitas sinar LED $2400 \mathrm{~mW} / \mathrm{cm}^{2}$ selama 2 detik dan intensitas sinar LED $600 \mathrm{~mW} / \mathrm{cm}^{2}$ selama 20 detik.

\section{PEMBAHASAN}

Polimerisasi resin komposit pada umumnya dapat dipengaruhi oleh beberapa faktor yang berkaitan dengan light curing unit dan komposisi komposit itu sendiri. Seperti yang dikatakan Kraig dan Swift (2011) bahwa faktor-faktor yang berkaitan dengan light curing unit mencakup arah dan jarak penyinaran, intensitas sinar, durasi penyinaran, distribusi spektrum, dan dispersi cahaya. ${ }^{8}$ Sedangkan faktor yang berkaitan dengan komposisi resin komposit mencakup jenis matriks resin, jumlah dan ukuran filler, dan warna resin komposit. Tidak terpenuhinya salah satu faktor diatas bisa mengakibatkan proses polimerisasi menjadi tidak sempurna yang hasilnya akan mempengaruhi beberapa parameter penting seperti kekuatan lentur, fatik, kelarutan, perubahan warna dan biokompatibilitas resin komposit.

Sumber dan intensitas sinar yang digunakan memiliki peranan penting pada proses polimerisasi resin komposit. Seiring perkembangan pengetahuan dan teknologi, sumber sinar yang digunakan untuk proses polimerisasi terus menerus berganti. Sampai saat ini diketahui 4 macam sumber sinar untuk polimerisasi resin komposit yaitu Quartz Tungsten Halogen (QTH), Plasma Arc Curing (PAC), Argon-ion Lasers (AL) dan yang paling sering digunakan saat ini adalah Light Emitting Diodes (LED). Dari beberapa sumber sinar diatas, QTH dan LED diketahui tidak mempengaruhi stabilitas warna pada resin komposit setelah polimerisasi.

LED dengan ultra high intensity diperkenalkan pada tahun 2010 dengan intensitas $4000 \mathrm{~mW} /$ $\mathrm{cm}^{2}-5000 \mathrm{~mW} / \mathrm{cm}^{2}$ dan durasi penyinaran 1 dan 3 detik. Durasi penyinaran yang sangat singkat ini memberikan kenyamanan kepada dokter gigi maupun pasien dalam segi waktu. Penggunaan intensitas yang sangat tinggi pada polimerisasi resin komposit akan mengakibatkan waktu polimerisasi menjadi sangat singkat (rapid polymerization). Randolph dkk. (2014) menyatakan dengan waktu polimerisasi yang sangat singkat, pulpa tidak akan terpapar panas dari sinar LED dalam waktu yang lama sehingga tidak menyebabkan iritasi pada pulpa. Selain itu, tidak ditemukan perbedaan yang signifikan microshrinkage pada penelitian yang membandingkan rapid polymerization dengan polimerisasi normal. ${ }^{9}$ Meskipun terdapat banyak keuntungan dalam penggunaan LED dengan intensitas sinar yang tinggi, belum ada penelitian yang menyatakan bahwa polimerisasi yang sempurna pada resin komposit akan terjadi dengan rapid polymerization. Hasil penelitian Nurlatifah dkk (2018) menunjukkan bahwa diametral tensile strength pada resin komposit yang disinari dengan LED dengan intensitas sinar yang tinggi (1200 mW/cm2) mengalami penurunan dibandingkan dengan resin komposit yang disinari dengan LED dengan intensitas sinar $420 \mathrm{~mW} / \mathrm{cm} 2) .{ }^{10}$

Penurunan kekuatan resin komposit kemungkinan terjadi akibat polimerisasi yang tidak sempurna yang dipengaruhi oleh banyak faktor seperti komposisi monomer, intensitas sinar, isi filler pada matriks resin dan transmisi sinar pada material. Manhal dkk (2012) menyatakan bahwa derajat polimerisasi memiliki hubungan yang erat dengan lama penyinaran cahaya dibandingkan dengan intensitas cahaya yang keluar. Karena pada saat penyinaran dengan waktu yang lebih lama, molekul dapat teraktivasi dan memulai polimerisasi, serta panas yang ditimbulkan dapat menginisiasi poses propagasi (perpanjangan rantai) dan kondisi ini dapat menigkatkan polimerisasi. Efek yang ditimbukan berupa efek terhadap kelarutan, stabiitas dimensi, dan perubahan warna. ${ }^{11}$

Pada penelitian ini digunakan resin komposit flowable Any-com ${ }^{\mathrm{TM}}$ flow dengan warna A2. Resin komposit flowable Any-com ${ }^{\mathrm{TM}}$ flow merupakan resin komposit flowable nanohibrida dengan komposisi matriks Bis-GMA, Bis-EMA, dan UDMA, serta menggunakan inorganic filler dengan dua ukuran partikel 
$0.01 \mu \mathrm{m}-2,5 \mu \mathrm{m}$ sebanyak $70 \%$ dari kandungan. Dua puluh sampel resin komposit yang digunakan pada penelitian ini disinar menggunakan LEDEX WL-090 dengan intensitas sinar LED $2400 \mathrm{~mW} / \mathrm{cm}^{2}$ selama 2 detik dan intensitas sinar LED $600 \mathrm{~mW} / \mathrm{cm}^{2}$ selama 20 detik

Seluruh sampel pada penelitian ini menggunakan warna komposit nanohibrid yang sama yaitu warna A2. Hal ini dilakukan untuk menghindari terjadinya "colorant effect" yang mungkin terjadi pada saat fotopolimerisasi. ${ }^{11}$ Beberapa penelitian menunjukkan bahwa komposit yang berwarna lebih terang dapat di-cure dengan kedalaman yang lebih besar daripada komposit yang berwarna lebih gelap. Penelitian Julian dkk (2012) melaporkan bahwa komposit resin warna A2 mempunyai nilai derajat konversi secara signifikan lebih besar dibandingkan dengan warna gelap A4. Pada komposit yang berwarna lebih gelap akan menyerap lebih banyak cahaya sehingga akan mengurangi penetrasi cahaya ke dalam bahan resin. ${ }^{12}$

Dalam penilaian warna terdapat tiga nilai yang digunakan untuk membedakan warna yaitu light, chrome dan hue. Ketiga nilai ini dapat mendeskripsi- kan dan menetukan tiap warna yang terlihat. Light merupakan kualitas warna yang membedakan antara warna terang dengan warna gelap. Warna terang dapat diartikan dengan light yang tinggi dan sebaliknya. Hal ini dapat juga dipengaruhi oleh jarak antara objek dan sumber cahaya. Chrome merupakan kualitas warna yang dapat membedakan antara warna yang kuat dengan yang lemah. Chrome merupakan saturasi atau intensitas dari suatu warna spesifik. Semakin tebal material maka efek warna yang timbul akan semakin intens. Semakin tinggi nilai chrome, maka warnanya semakin pekat atau intens. Hue merupakan kualitas warna yang dapat membedakan antara warna yang satu dengan warna yang lain. Hue adalah warna yang murni tanpa dicampur hitam, putih dan abu-abu. Untuk mengidentifikasi hue adalah dengan cara membedakan warna chrometic satu dengan yang lainnya, seperti warna jingga atau biru dari biru kehijauan. ${ }^{13}$

Hasil dari Resin komposit flowable Any-com ${ }^{\mathrm{TM}}$ flow A2 disinar LEDEX WL-090 dengan intensitas sinar LED $2400 \mathrm{~mW} / \mathrm{cm}^{2}$ selama 2 detik dan intensitas sinar LED $600 \mathrm{~mW} / \mathrm{cm}^{2}$ selama 20 detik dapat dilihat pada Gambar 2.

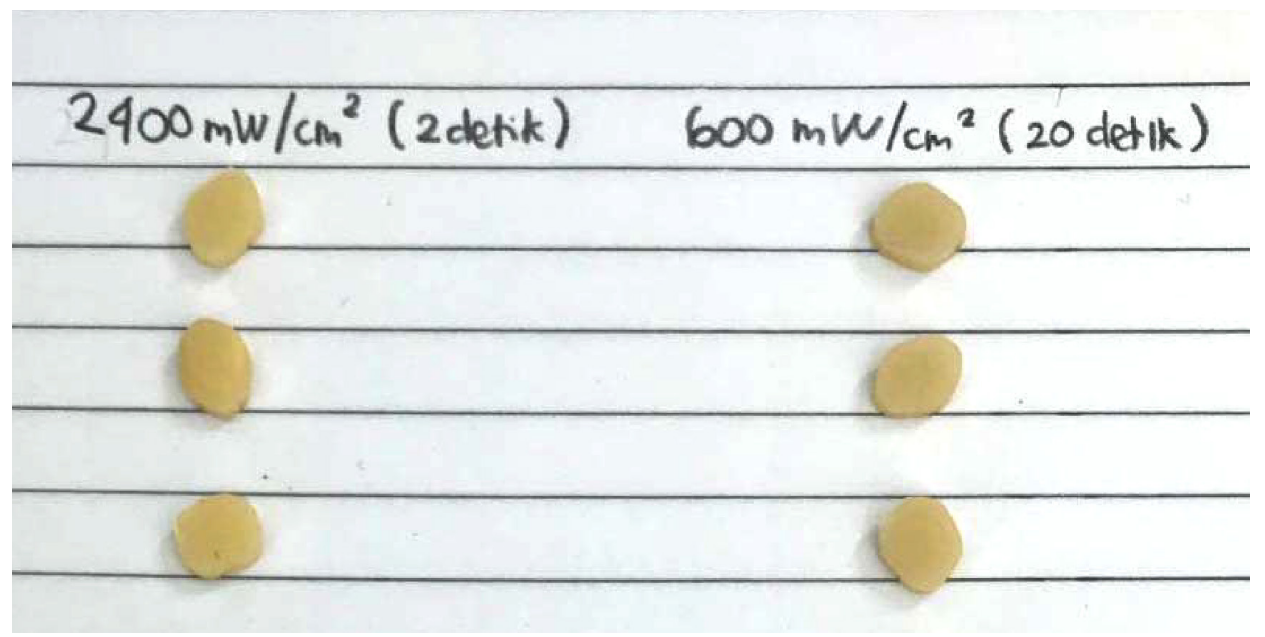

Gambar 2. Hasil sampel Resin Komposit Flowable yang disinari dengan intensitas sinar LED $2400 \mathrm{~mW} / \mathrm{cm}^{2}$ dengan intensitas sinar LED $600 \mathrm{~mW} / \mathrm{cm}^{2}$

Berdasarkan data hasil penelitian yang tertera pada tabel 2 diketahui terdapat perbedaan rerata light, chrome, dan hue pada kelompok perlakuan dengan intensitas sinar LED $2400 \mathrm{~mW} / \mathrm{cm}^{2}$ dengan intensitas sinar LED $600 \mathrm{~mW} / \mathrm{cm}^{2}$. Dari hasil uji normalitas data terlihat bahwa seluruh data berdistribusi data normal karena ( $\mathrm{p}>0,05)$, Hasil uji $\mathrm{t}-T$ independent menunjukan sig. $\mathrm{p}<0,05$ maka terdapat perbedaan pengaruh intensitas sinar LED $2400 \mathrm{~mW} / \mathrm{cm}^{2}$ selama 2 detik dan intensitas sinar LED $600 \mathrm{~mW} / \mathrm{cm}^{2}$ selama 20 detik terhadap warna light, chrome dan hue pada resin komposit flowable. Dalam penelitian yang dilakukan ini didapatkan hasil bahwa terdapat perbedaan pengaruh intensitas sinar LED $2400 \mathrm{~mW} / \mathrm{cm}^{2}$ selama
2 detik dan intensitas sinar LED $600 \mathrm{~mW} / \mathrm{cm}^{2}$ selama 20 detik terhadap warna resin komposit flowable. Hal ini disebabkan penggunaan sinar LED $2400 \mathrm{~mW} / \mathrm{cm}^{2}$ selama 2 detik akan mempercepat proses polimerisasi resin komposit. Dalam proses polimerisasi terjadi perubahan monomer - monomer menjadi polimer yang disebut dengan nama derajat konversi. Derajat konversi yang meningkat maka proses curing yang terjadi lebih cepat, begitu juga pergerakan monomer untuk membentuk polimer. Teori ini sesuai dengan penelitian Nicola dkk. (2011) yang menyatakan bahwa semakin besar intensitas sinarnya maka derajat konversinya semakin besar dan semakin singkat proses curing-nya. ${ }^{14}$ 
Derajat konversi juga dipengaruhi oleh kandungan champhorquinone dalam resin komposit. Dimana kita ketahui bahwa champhorquinone ini merupakan fotoinisiasi polimerisasi resin komposit. Sesuai dengan penelitian Luis dkk. (2012) bahwa semakin banyak kandungannya maka semakin banyak juga efek warna kekuningan di resin komposit. Dengan intensitas sinar LED $2400 \mathrm{~mW} / \mathrm{cm}^{2}$ maka resin komposit yang terpolimerisasi akan lebih cepat terlihat warna kekuningannya dari champhorquinone, terbukti pada Gambar 2 diatas. ${ }^{15}$

\section{KESIMPULAN DAN SARAN}

Berdasarkan hasil penelitian mengenai pengaruh perbedaan intensitas sinar LED $2400 \mathrm{~mW} /$ $\mathrm{cm}^{2}$ dan intensitas sinar LED $600 \mathrm{~mW} / \mathrm{cm}^{2}$ terhadap warna resin komposit flowable, dapat disimpulkan bahwa terdapat perubahan warna yang signifikan antara kelompok intensitas sinar LED $2400 \mathrm{~mW} / \mathrm{cm}^{2}$ dengan kelompok intensitas sinar LED $600 \mathrm{~mW} / \mathrm{cm}^{2}$. Perubahan warna yang signifikan ini terjadi pada nilai light, chrome, dan hue dari resin komposit flowable yang disinari dengan intensitas sinar LED $2400 \mathrm{~mW} /$ cm2 selama 2 detik. Intensitas sinar LED $2400 \mathrm{~mW} /$ $\mathrm{cm}^{2}$ juga mempercepat derajat konversi dari resin komposit flowable. Semakin tinggi derajat konversi maka semakin cepat pula reaksi polimerisasi yang terbentuk. Keterbatasan penelitian ini adalah bahwa penelitian ini menggunakan resin komposit flowable yang belun tentu hasilnya sama dengan jenis komposit lainnya.

Saran dari penelitian ini diharapkan hasil penelitian ini dapat menjadi data awal untuk penelitian selanjutnya dan juga diharapkan adanya penelitian lebih lanjut mengenai perubahan warna untuk jenis resin komposit lainnya.

\section{DAFTAR PUSTAKA}

1. Sidiqa, A. N. \& Soerachman, B. Pengaruh Penyinaran Qth Dan Led Pada Kekuatan Tekan Resin Komposit Bulkfilldengan Berbagai Ketebalan. J. Mater. Kedokt. Gigi, 2017: 6, 7-13.

2. Anusavice, K. J. Phillips' Science of Dental Materials (Anusavice Phillip's Science of Dental Materials) $12^{\text {th }}$ ed. Elsevier Saunders, 2013: 588.
3. Lestari, S. Efek Lama Penyinaran Terhadap Kebocoran Tepi Tumpatan Resin Komposit Flowable. Stomatognatic- J. Kedokt. Gigi, 2015: 9, 1-5.

4. Nugrahenny, G., Nughraheni, T. \& Hadriyanto, W. Pengaruh Teknik Penyinaran Ramped, Pulse-Delayed, Dan Konvensional Terhadap Kekerasan Mikro Resin Komposit Nanofil. J. Kedokt. Gigi, 2016: 7, 68-72.

5. Bektas, O. O., Hürmüzlü, F. \& Eren, D. Effect of the Composite Curing Light Mode on Polymerization Shrinkage of Resin Composites. Cumhur. Dent. J., 2012: $15,1-6$.

6. Leprince, J. G., Palin, W. M., Hadis, M. A., Devaux, J. \& Leloup, G. Progress in Dimethacrylate-Based Dental Composite Technology and Curing Efficiency. Dent. Mater., 2013: 29, 139-156.

7. Ilday, N. O., Bayindir, Y. Z., Bayindir, F. \& Gurpinar, A. The Effect of Light Curing Units, Curing Time, and Veneering Materials on Resin Cement Microhardness. $J$. Dent. Sci., 2013: 8, 141-146.

8. Vandewalle, K. S. \& Swift Edward J., J. R. Estimated Light Exposure Time for Composite Resin Restorative Materials. J. Esthet. Restor. Dent., 2011: 23, 201-204.

9. Randolph, L. D. et al. The Effect of Ultra-Fast Photopolymerisation of Experimental Composites on Shrinkage Stress, Network Formation and Pulpal Temperature Rise. Dent. Mater., 2014: 30, 1280-1289.

10. Nurlatifah, A., Eriwati, Y. K. \& Indrani, D. J. The Effect of the Curing Time of an Ultra-High Intensity LED Curing Unit on Diametral Tensile Strength of Packable Composite Resin. J. Phys. Conf. Ser., 2018: 1073, 1-6.

11. S, M. A. M. B. D. \& Sc, M. Effect of Curing Mode on Immediate and Post-Irradiation Depth of Cure of a SiloraneBased and Methacrylate- Based Posterior Composites (in Vitro Comparative Study ). 2012: 24, 9-16.

12. Leprince, J. G. et al. New Insight into the "Depth of Cure" of Dimethacrylate-Based Dental Composites. Dent. Mater., 2012: 28, 512-520.

13. Cochrane, S. The Munsell Color System: A Scientific Compromise from the World of Art. Stud. Hist. Philos. Sci. Part A, 2014: 47, 26-41.

14. Scotti, N. et al. New-Generation Curing Units and Short Irradiation Time: The Degree of Conversion of Microhybrid Composite Resin. Quintessence Int. (Berl)., 2011: 42, 89-95.

15. Schneider, L. F. J., Cavalcante, L. M., Prahl, S. A., Pfeifer, C. S. \& Ferracane, J. L. Curing Efficiency of Dental Resin Composites Formulated with Camphorquinone or Trimethylbenzoyl-Diphenyl-Phosphine Oxide. Dent. Mater., 2012: 28, 392-397. 